BJHS: Themes 4: 273-281, 2019. C British Society for the History of Science 2019. This is an Open Access article, distributed under the terms of the Creative Commons Attribution licence (http://creativecommons.org/licenses/by/4.0/), which permits unrestricted re-use, distribution, and reproduction in any medium, provided the original work is properly cited.

doi:10.1017/bjt.2019.4 First published online 20 September 2019

\title{
Commentary: collect or die
}

\section{JAMES DELBOURGO *}

The acquisition of the final item would in effect denote the death of the subject

Jean Baudrillard

In his amusing and sometimes outrageous analysis of collecting - a heady consumer-age cocktail of psychoanalysis and sociological reflection - Jean Baudrillard stresses the dangers of completing collections. The end of the collection - the private collection means the death of the collector. To collect is to live, or at least not to perish: 'the collection staves off the menace of death'. Collect or die. Baudrillard's account owes much to Freud, who had himself earlier written that 'a collection to which there are no new additions is really dead'. This claim, however, is far from universally valid. Christian naturalists like Hans Sloane (1660-1753) tended to believe it possible to collect complete series of species, for example, because they trusted that the natural world had not substantially altered since the divine act of Creation. 'There are very few things which I lack', he once confidently observed to a naturalist colleague. Completion inspired not foreboding but pious thoughts of happy termination and postlapsarian redemption. The hortus conclusus modelled natural history as a complete garden that recuperated the loss of Eden, and the total catalogue provided a road map to paradise and eternal life. ${ }^{1}$

In early twenty-first-century Western societies, however, alarm bells are ringing about the end of collections. The first bell is political and tolls most loudly in Paris. 'I cannot accept that a large part of cultural heritage from several African countries is in France', declared President Emmanuel Macron in November 2017 at the University of Ouagadougou in Burkina Faso. 'African heritage can't just be in European private collections and museums ... I want the conditions to be met for the temporary or permanent restitution of African heritage to Africa'. So there are 'conditions' to this promise of

\footnotetext{
* Rutgers University, 104 Van Dyck Hall, 16 Seminary Place, New Brunswick, NJ 08901, USA. Email: jdelbourgo@history.rutgers.edu.

James Delbourgo is Professor of History at Rutgers University. His book Collecting the World: The Life and Curiosity of Hans Sloane (2017) won the Louis Gottschalk and Annibel Jenkins Prizes from the American Society for Eighteenth-Century Studies and the Leo Gershoy Award from the American Historical Association.

1 Jean Baudrillard, 'The system of collecting' (1968), in John Elsner and Roger Cardinal (eds.), The Cultures of Collecting, Cambridge, MA: Harvard University Press, 1994, pp. 7-24, 18; John Forrester, 'Mille e tre: Freud and collecting', in Elsner and Cardinal, op. cit., p. 227; James Delbourgo, Collecting the World: The Life and Curiosity of Hans Sloane, London: Allen Lane, 2017, p. 270; Richard Drayton, Nature's Government: Science, Imperial Britain and the 'Improvement' of the World, New Haven, CT: Yale University Press, 2000, p. 137.
} 


\section{4}

James Delbourgo

museological decolonization, but art historian Bénédicte Savoy, who has been tasked with helping to realize the French president's ambition, heralded Macron's initiative hopefully as a 'restitution revolution'. ${ }^{2}$

Restitution by no means automatically entails a sweeping repatriation of objects. Yet restitution talk - or simply acknowledging museums' histories and collections' provenance - conjures the spectre of the end. My own experience discussing Hans Sloane and the origins of the British Museum, including Sloane's extensive involvement with the Atlantic slave trade, suggests how common such reactions remain, especially in Britain, where colonial history is largely ignored rather than confronted. My biography of Sloane does not press an explicit restitutionist case but I have nonetheless been repeatedly asked does this mean everything must now go back? And what about the Elgin Marbles? Arguments about those Greek stones notwithstanding, there are hardly so many repatriation claims that they would empty Western museums, as is often supposed. Returns via NAGPRA, for example, have not destroyed American museums, and it is only right that many genuine cases of wrongful seizure be candidates for repatriation. But as Nicholas Thomas has argued, there is also a risk that possibilities for creating new museological programmes that build accurate provenance narratives and encourage greater international exchange across the globe may get reduced to a political argument over sending things back (as has happened between Athens and London). Another way to put this is that repatriating collections won't necessarily bring about the decolonizing of Western museum narratives - there needs to be a cultural programme for telling museum stories about relationships between peoples across history, and not just a legal corrective. Savoy and her co-author Senegalese scholar Felwine Sarr have published their report and recommended that all African objects in French collections which cannot be demonstrated to have been 'legitimately' acquired should now be permanently returned to the African continent. At the time of writing (16 February 2019), however, it is not clear whether Macron and his administration will agree or, for that matter, how long he will remain in power. ${ }^{3}$

Macron's initiative has nonetheless already provoked unprecedented radical visions of the end - the end of the collection, the museum, the prestige it confers on Western countries, and even some version of civilization, since so much has been staked on imagining museums as repositories of civilization and instruments of civic improvement. Whatever form the Macroniste millennium takes - the geopolitical wit of a man who acknowledges the 'crimes' of colonialism while welcoming Donald Trump with a military parade should not be underestimated - it promises a reckoning much dreaded or much

2 Vincent Noce, 'Quai Branly-Jacques Chirac Museum in Paris is ready to return African art', Art Newspaper, 4 January 2018 at www.theartnewspaper.com/news/ethnographic-museum-ready-to-returnafrican-art; Bénédicte Savoy, 'The restitution revolution begins', Art Newspaper, 16 February 2018 (originally Le Monde, 12 January 2018), at www.theartnewspaper.com/comment/the-restitution-revolutionbegins.

3 Tristram Hunt, Hartmut Dorgerloh and Nicholas Thomas, 'Restitution report: museum directors respond', Art Newspaper, 27 November 2018, at www.theartnewspaper.com/comment/restitution-reportmuseums-directors-respond; on NAGPRA see Ann Kakaliouras, this issue; on the different forms restitution can take see Laura Peers and Alison K. Brown (eds.), Museums and Source Communities: A Routledge Reader, London: Routledge, 2003. 
longed-for, depending on how one regards Walter Benjamin's famous statement that 'there is no document of civilization which is not at the same time a document of barbarism'. How French initiatives may influence museums in other countries remains an intriguing open question. ${ }^{4}$

The second alarm is economic and rings most loudly in London - another great former seat of empire. I say 'economic', but it is no less political than the first. I refer to the regime of neoliberal museology in the UK, where a decade of cuts to public funding justified by 'austerity' in the aftermath of the 2008 banking crisis has severely undermined British museums, their staff and their working conditions. Long-standing claims to the rightful stewardship of the world's heritage - because we can take care of it better than its countries of origin - collide spectacularly with the elimination of adequate provision for even basic maintenance, in an ideological environment where lower taxes invite the privatization of public services. The latest name for this museological Götterdämerung is Carillion: the private facilities contractor to which the British Museum outsourced its physical upkeep in 2013 and which collapsed in early 2018, causing redundancies, wiping out staff pensions and leaving the BM (one of the five most visited museums in the world) without proper maintenance. And this comes before Brexit, with the likelihood of severe economic disruption, particularly if there is no legal and commercial exit agreement between Britain and the European Union. 'Why Collect?', a report chaired by historian David Cannadine and published in February 2018, documented the decline in collecting by British art museums, raising the prospect of sell-offs and British collections becoming 'inert and lifeless'. Collect or die. Even leading American institutions seem prone to current crunches. For the first time, that impoverished institution the Metropolitan Museum of Art now charges visitors from outside the New York area twenty-five dollars for admission. As artist-activist Andrea Fraser has documented, dizzying revenues from art sales correlate with deepening inequality, as megacollectors lobby politicians to shrink the tax base. Will the public museum survive under neoliberalism or just become another privatized public good?5

There is, of course, no self-evident reason why museum collections should endure. The fire which tore through the National Museum in Rio de Janeiro on 2 September 2018 is a particularly painful case in point, as it destroyed a large portion of irreplaceable collections that count as Brazilian, if not global, natural and cultural patrimony. The disaster of the conflagration confirms the argument of Regina Horta Duarte, the leading historian of that museum, that the fortunes of museums remain continually vulnerable to changing governmental and economic regimes, since funding cuts had already raised alarms

4 Andrew McClellan, The Art Museum from Boullée to Bilbao, Berkeley: University of California Press, 2008; Walter Benjamin, 'Theses on the philosophy of history' (1940), in Benjamin, Illuminations, trans. Harry Zohn, New York: Schocken Books, pp. 253-264, 256.

5 Mark Serwotka, 'Carillion collapse shows the fiasco of privatisation', Huffpost, 29 January 2018, at www.huffingtonpost.co.uk/entry/privatisation_uk_5a6f09a7e4b06e2532698b2e; conversations with participants during Tales from the Crypt conference on museum storage, organized by Mirjam Brusius and Kavita Singh, Victoria \& Albert Museum, October 2014; David Cannadine, 'Why collect? A report on museum collecting today', Art Fund, 2018, at www.artfund.org/assets/downloads/why-collect-report.pdf, accessed February 2019; Andrea Fraser, 'Trusteeship in the age of Trump', October (2017) 162, pp. 31-38, 32; and Fraser, 2016: In Museums, Money and Politics, Cambridge, MA: MIT Press, 2018. 
about the collections' safety. This is something we seem particularly unwilling to acknowledge in the global North, which projects an image of timeless public stability to reinforce claims to rightful stewardship, but is especially called into question by fiascos like Carillion. ${ }^{6}$

The intriguing essays in this issue explore many ways collections end. Jenny Bangham, for example, explains how living collections of Drosophila flies get deaccessioned when they are deemed to lose scientific relevance. Ann Kakaliouras describes the repatriation and reburial of Kennewick Man (reminiscent of the return of Sara Baartman, the 'Hottentot Venus', to South Africa in 2002), as well as the end of the category 'Palaeoamericans'. Boris Jardine shows how historical scientific instruments were removed from the Cavendish Laboratory in Cambridge. In Sloane's case, virtually none of his 1,886 quadrupeds survive, because they fell victim to the sacrificial 'bonfires' of rotting specimens carried out by early British Museum curators. There are countless examples of theft, loss and return, from the London Natural History Museum's repatriation of human remains to Torres Strait Islanders to the Getty sending stolen antiquities back to Italy. Bristol's Empire and Commonwealth Museum opened in 2002 but closed in 2009 after unlawful sales from its collections. There is nothing inherently stable about the status or value of collections, and their physical survival requires continual labour. Not for nothing is the dread of dispersion the abiding fear of the collector, as Benjamin long ago observed, one that cuts right across the spectrum of class and wealth from art collectors to lovers of collectibles. ${ }^{7}$

But what appears even more striking in these essays is the suggestion that old collections often don't die but linger, drift and morph, even as their value remains unclear. They have a tenacious capacity for transformation and adaptation. Sloane's substantial plant and seed collections have been preserved virtually intact since the eighteenth century, despite passing decades and in some cases even centuries without use. The contributors to this issue compellingly dramatize the point that endings often entail beginnings, as new regimes of value succeed old ones, even if collections are left in a limbo of ambiguous continuity where they survive because curators aren't yet convinced they won't prove valuable in future. ${ }^{8}$

6 Regina Horta Duarte, Activist Biology: The National Museum, Politics and Nation Building in Brazil (trans. Diane Grosklaus Whitty), Tucson: University of Arizona Press, 2016; 'Brazil museum fire: funding cuts blamed as icon is gutted', BBC News Online, 3 September 2018, at www.bbc.com/news/world-latinamerica-45398084, accessed February 2019.

7 Sadiah Qureshi, 'Displaying Sara Baartman, the "Hottentot Venus"', History of Science (2004) 42, pp. 233-257; Maev Kennedy, 'Natural History Museum returns bones', The Guardian, 10 March 2011, at www.theguardian.com/culture/2011/mar/10/museum-returns-torres-strait-islanders-bones; Elisabetta Povoledo, 'Getty agrees to return 40 antiquities to Italy', New York Times, 2 August 2007, at www. nytimes.com/2007/08/02/arts/design/02gett.html; Steven Morris, 'Row erupts over British Empire Museum's “lost” artefacts', The Guardian, 10 December 2012, at www.theguardian.com/culture/2012/dec/10/rowbritish-empire-museum-artefacts; Walter Benjamin, The Arcades Project (trans. Howard Eiland and Kevin McLaughlin), Cambridge, MA: Belknap Press, 1999, p. 211; Delbourgo, op. cit. (1), Chapter 7; Susan Pearce and Paul Martin (eds.), The Collector's Voice, vol. 4: Contemporary Voices, Aldershot: Ashgate, 2002.

8 James Delbourgo, 'Sir Hans Sloane's milk chocolate and the whole history of the cacao', Social Text (2011) 29, pp. 71-101; Arjun Appadurai (ed.), The Social Life of Things: Commodities in Cultural Perspective, Cambridge: Cambridge University Press, 1986. 
Helen Curry demonstrates how the end of individual seed collections coincided, as in the case of Burt Berrier, in the creation of a new centralized and collectivized seed database, linking the integration of personal collections to processes of standardization (as does Bangham). Ostensibly resolved processes of categorization may always reopen under new curatorial and political regimes, as Dahlia Porter's exploration of how anatomist William Hunter's collections have been reorganized since his death reminds us. Immortalization via institutionalization inevitably means transformation. Ana María Gómez López explores the persistence of the fossil collections and collages of palaeontologist Johannes Weigelt at the Geiseltalmuseum, notwithstanding its closure to the public in 2011. The banishment of historic scientific instruments from the Cavendish, Jardine points out, eventually led to the curation of such instruments as museum collections in their own right. Using the case of the Kiel anatomist Spee, Nick Hopwood ruminates on how retired collectors themselves seem never wholly to withdraw but to haunt those collections they have cared for over many years with an enduringly 'possessive love'.

In Kakaliouras's account, the repatriation of Kennewick Man and the retiring of the category of 'Palaeoamericans' can be seen as endings which are also acts of resumption, granting sacred remains and historical narratives back to Native Americans. Ricardo Roque recounts the story of how a series of colonial Portuguese bloodgroup cards, produced as a racial biopolitical survey of Asian and African subject populations, fell into irrelevance over time. He shows how these objects then revived in new ways, as they became tangled up with the anthropobiologist Maria Emilia Castro e Almeida's efforts to vindicate the memory of her father António de Almeida, the collection's original mastermind. The Almeida saga is a poignant example of how collections don't end, don't stay the same, and - despite their institutionalization and even obsolescence - take on new and often intense personal value. Roque's story also illustrates the tendency of many scientific collections to end up as fodder not for scientists, but for historians.

Something similar may be said of the vexing tale told by Emma Kowal of the surviving statue of colonial anthropologist Baldwin Spencer in the collections of Museum Victoria in Australia. Curators have not disposed of the statue, and continue to differ on where to put it and how to display it - a striking example of value defying both elimination and positive articulation. Of course, this is just one instance of our current Statue Wars, which wrestle with the question of what is to be gained or lost from preserving or removing. Retain, rewrite or remove? There is no better symbol of such confusion than the bizarre spectacle of the tarpaulins that were placed over the statue of Robert E. Lee in Charlottesville, Virginia, only to be repeatedly torn down and put up again during 2017-2018. The quandaries of data collection underscore the point further. As David Skinner and Matthias Wienroth observe in their account of the UK police national DNA database, deletion is hard. Mark Zuckerberg's Congressional testimony on Facebook's alleged role in compromising the 2016 US elections increased public awareness that social media data collection is continual, apparently unavoidable and virtually 
undeletable. But will it matter? Is digital iconoclasm now both a technical and political impossibility? ${ }^{9}$

The stories told by these essays recall recent work by Mirjam Brusius and Kavita Singh examining the importance of storage in the constitution of the museum. Storage is a kind of zombie facility that neither gives life nor brings death but allows most objects to survive (the book's vampiric subtitle is Tales from the Crypt) on a kind of undead minimalist life support. In my contribution to that volume, I concluded that storage reveals the twilit conditions of most collections' careers. Storage manages potentially vexing questions of value by implicitly promising that one day stored items will prove their usefulness, deferring precise judgements on specific objects to a seemingly endless future. Storage is the thing since, for better or worse, we live at a time of swollen accumulation when deaccessioning remains frowned upon, although the Baltimore Museum of Art now plans to sell works by Warhol, Rauschenberg and others to buy more art by women and people of colour. As British collections have ceased to grow in a global economy where Asian, Gulf state and Russian fortunes now exceed American ones (let alone those of Europeans), it is little wonder that pressure is increasingly placed on wringing greater value from imperial-era collections, whether via loan programmes, attracting new foreign patrons or ever greater numbers of tourists. (Cannadine is arguably wrong about the need to collect: since over 90 per cent of major museums' holdings sit in storage, less collecting might promote more use of what they actually have.) 'Unlock the power of art', US Trust (the private wealth-management branch of Bank of America) invites its high-net-worth clients, to exploit their collections as capital resources, while advocates of 'Art Market 2.0' are now planning total financialization through the selling of shares in individual works of art. Whether one is spending heavily or no longer collecting the way one used to, collections are precious commodities. And although Europe's empires are lost, their successors still trade on venerable brand names to broker new collections around the world, as shown by the expansion of Sotheby's and Christie's into Asian art and antiquities markets, and the way collectors in regions such as the Middle East see institutions like the British Museum as partner repositories who can legitimate their own collecting on the world stage. ${ }^{10}$

9 Matthew Haag, 'Judge orders tarps removed', New York Times, 27 February 2018, at www.nytimes.com/ 2018/02/27/us/charlotesville-confederate-monuments.html; Jessica Kang and Kevin Roose, 'Zuckerberg faces hostile Congress', New York Times, 11 April 2018, at www.nytimes.com/2018/04/11/business/zuckerbergfacebook-congress.html; Elena Aronova, Christine von Oertzen and David Sepkoski (eds.), Data Histories, Osiris (2017) 32.

10 Mirjam Brusius and Kavita Singh (eds.), Museum Storage and Meaning: Tales from the Crypt, London: Routledge, 2017; Julia Halperin, 'It is an unusual and radical act', Artnet, 30 April 2018, at https://news.artnet. com/market/baltimore-museum-deaccession-1274996; Sonja Mejcher-Atassi and John Pedro Schwartz (eds.), Archives, Museums and Collecting Practices in the Modern Arab World, Aldershot: Ashgate, 2012; Evan Beard, 'Unlocking the power of art', US Trust/Bank of America, at www.ustrust.com/insights/art.html, accessed May 2018; Duncan MacDonald-Korth, Vili Lehdonvirta and Eric Meyer, Art Market 2.0: Blockchain and Financialisation in Visual Arts, London: The Alan Turing Institute, 2018; Shareen Brysac and Karl Meyer, The China Collectors: America's Century-Long Hunt for Asian Art Treasures, New York: Palgrave Macmillan, 2015, pp. 7-10; 'Mohammed Afkhami: the high-rise collector', Reframe Iran (2016), at www.youtube.com/watch?v=675s_G1guXs. 
My final point is not about how collections end - or don't - but how they begin, and when and where. The excellent essays in this issue mostly concentrate on the biological and anthropological sciences of the long twentieth century and their legacies in Britain and Europe, and their former colonies. But it would be fascinating and important in future to think about when and where such stories fall in historical time, and how the long Western post-colonial present relates to larger patterns of world history. The history of collecting has typically been framed as a European or Western story, with the rest of the world figuring essentially as a source community for writing the history of European empires and Western institutions, or indeed hardly figuring at all, as in the magisterial work of Susan Pearce, which refers exclusively to a distinctive European tradition in collecting. ${ }^{11}$

The economic ascendancy of China, the Gulf states and other nations, however, now raises new questions about the old beginnings and endings of purposeful accumulation. While Western media herald the 'new' art collectors in China - whose art market now outstrips that of the US and by far that of the UK - the collecting traditions of Asia are in some ways rather older than those of the West. It's just that, unlike the Europeans and Americans who made great collections long after them, they didn't produce enduring museums that survive into our present. Two brief examples illustrate the point. Sheikh Hamad bin Abdullah Al Thani of Qatar has in recent years amassed one of the world's great collections of Mughal-era gemstones and jewels. Qatar's oil fortunes may be new but the sheikh's ambitions are not; rather, they demonstrate a historical continuity with the collecting ambitions of early modern South Asian emperors, whose gems literally outshone their equivalents in the West. Consider also the case of Jerry Yang, the Taiwanese American Internet entrepreneur who made his fortune as co-founder of Yahoo!, and who, on the advice of friends, began to collect Chinese calligraphy. Again, Yang's fortune was new but his personal identification with specific forms of heritage and his collecting decisions were historically minded, leading him to calligraphy - one of the great mainstays of imperial Chinese collections under successive dynasties. 'It allows me to understand the past and see the future', he writes. 'It brings me back to my culture and heritage, but also to watch the Chinese people of today as they embrace their past'. The point is not that there's nothing new under the sun, but that there are long-term patterns of cross-cultural change and revival - not to mention conventions of legitimacy and prestige rooted in historical objects, as the recuperation of Mughal jewellery and Ming calligraphy suggests - which help us to see that collecting has a deep world history of which the modern West forms but one part. It is right and necessary that Westerners understand their own collecting heritage - and champion a liberal and reflexive understanding of its legacies - but we need to be more cognizant that Sloanes and Gettys are neither the first nor the last to dream of collecting the

11 Richard Drayton, David Motadel, David Bell and Jeremy Adelman, 'Discussion: the futures of global history', Journal of Global History (2018) 13, pp. 1-21; Susan Pearce, On Collecting: An Investigation into Collecting in the European Tradition, London: Routledge, 1995; and Susan Pearce et al. (eds.), The Collector's Voice: Critical Readings in the Practice of Collecting, 4 vols., Aldershot: Ashgate, 2000-2002. 
world. We need to recast the history of collecting with such interesting geopolitical facts in mind. ${ }^{12}$

When it comes to the natural sciences, contrasting patterns of Western contraction and Chinese investment are easily observed as well, as dreams of total collection shift from Western to Asian worlds. China is now developing the world's largest collection of human and non-human genome data at the Shenzhen-based BGI Genomic Services - the world's largest genomic sequencing centre - where director Huanming Yang has declared his ambition to collect the DNA of every living organism on Earth. Of course, the Chinese have long traditions of collecting in fields such as botany and ethnography, even if many Westerners aren't aware of this, since Western identity has been predicated on various narratives of exceptionalism, the clearest example of which is the allegedly unique character of modern Western science. CERN's Large Hadron Collider, built by the European Union to collect information from experimental work in particle physics, makes for a striking contrast with the eclipse of NASA, owing to the decline of federal funding for large-scale US science projects, though the future of the EU itself remains in doubt. In America, it is entrepreneurial data collectors like Craig Venter and Zuckerberg who capture the imagination today, rather than national endeavours like the Apollo moon missions. But now China has FAST (the Five Hundred Metre Aperture Spherical Telescope): the world's largest ever radio telescope, which is to say, the largest physical instrument for collecting information in the history of the world. As Chinese astrophysicists like to comment, it is China's turn to revel in the luxury of pure science, envisioning a seemingly limitless accumulation of information with no obvious application. Despite this national pride, however, it is interesting to note the role played by foreign technicians on the project as well as the current difficulties FAST is experiencing in finding someone to run it. Perhaps, some Western journalists have snarkily suggested, some latter-day Jesuits will provide directorial assistance as in earlier centuries? ${ }^{13}$

12 Amin Jaffer, Beyond Extravagance: Gems and Jewels of Royal India, New York: Assouline, 2013; Michael Knight and Joseph Chang (eds.), Out of Character: Decoding Chinese Calligraphy, San Francisco: Asian Art Museum, 2013, p. 12; Jeanette Shambaugh Elliot and David Shambaugh, The Odyssey of China's Imperial Art Treasures, Seattle: University of Washington Press, 2005; Karen Exell, 'Collecting an alternative world: the Sheikh Faisal bin Qassim Al Thani Museum in Qatar', in Karen Exell and Trinidad Rico (eds.), Cultural Heritage in the Arabian Peninsula: Debates, Discourses, and Practices, Aldershot: Ashgate, 2014, pp. 51-70; Finbarr Flood, Objects of Translation: Material Culture and Medieval 'HinduMuslim’ Encounter, New Delhi: Permanent Black, 2009.

13 See www.genomics.cn/en/navigation/show_navigation?nid=256, accessed July 2018 (my thanks to Emma Kowal for this point); for the contrast between British and Chinese botany today see Rebecca Morelle, 'Kew Gardens funding cuts "recipe for failure”, BBC News Online, 4 March 2015, at www.bbc. com/news/science-environment-31715081; and 'Botany pavilion of the Beijing Expo 2019 vividly presents “The Incredible Wisdom of Plants”, Beijing Horticultural Expo 2019 website, 12 January 2018, at www. horti-expo2019.org/2018-01/12/content_50218756.htm (thanks to Mark Spencer for these references); Shannon Ellis, 'Biotech booms in China', Nature, 17 January 2018, at www.nature.com/articles/d41586018-00542-3; Laura Hostetler, Qing Colonial Enterprise: Ethnography and Cartography in Early Modern China, Chicago: The University of Chicago Press, 2001; Carla Nappi, The Monkey and the Inkpot: Natural History and Its Transformations in Early Modern China, Cambridge, MA: Harvard University Press, 2009; Stefan Helmreich, Alien Ocean: Anthropological Voyages in Microbial Seas, Berkeley: University of California Press, 2009, Chapter 5; Chris Buckley and Adam Wu, 'China hunts for scientific glory, and 
In eighteenth-century Britain, even the most inward-seeming of collectors gestured emphatically outward to earlier paragons of collecting, knowledge and power. In 1786, William Beckford published his Gothic novel Vathek. A cloistered British gentleman, Beckford set himself up in a forbidding Wiltshire country mansion, financed by his family's Jamaican plantations and intoxicated with orientalist fantasies like The Arabian Nights. In Vathek, he wrote of the pleasures and perils of accumulation by reimagining the adventures of the real Abbasid Caliph al-Wathiq ibn Mu'tasim of ninth-century Baghdad in fictional form. The caliph, Beckford wrote, was 'of all men the most curious', and had an entire palace insatiably stuffed with treasures and curiosities. 'Collect or die' may be an animating fiction but it is one many have lived by. Beckford was preoccupied with this dilemma and knew there was nothing really new about Europeans' exotic hoards. Ultimately, he was obliged to auction off his collections in the early nineteenth century. Wounding though this undoubtedly was, he would have recognized that as some collections ended, others began. He knew that great collectors of the past, from around the world, haunt their heirs with visions both of magnificence and oblivion. ${ }^{14}$

aliens, with new telescope', New York Times, 26 September 2016, at www.nytimes.com/2016/09/26/world/ asia/china-telescope-fast-space-seti.html; Joel Hruska, "China built the world's largest telescope, but has noone to run it', Extremetech, 7 August 2017, at www.extremetech.com/extreme/253714-china-built-worldslargest-telescope-no-one-run.

14 William Beckford, An Arabian Tale, London, 1786, 4; Susan Pearce and Ken Arnold (eds.), Collector's Voice, vol. 2: Early Voices, Aldershot: Ashgate, 2000, extract 57 introduction, 'William Beckford collects his fantasies'; James Noggle, The Temporality of Taste in Eighteenth-Century British Writing, Oxford: Oxford University Press, 2012, Chapter 6. 